\title{
HUBUNGAN ANTARA KEMAMPUAN BERKOMUNIKASI GURU TERHADAP KEAKTIFAN BELAJAR SISWA DI KECAMATAN MEDAN POLONIA
}

\author{
Nurmayani, Yulia Helnani Nasution \\ Surel : nurmayani111161@gmail.com
}

\begin{abstract}
This study aims to determine the relationship between teacher communication skills and student learning activeness in Medan Polonia sub-district, 2020/2021. This research is a correlation study using a quantitative descriptive approach. The subjects in this study were 30 teachers. As the criteria for the variable of teacher communication skills and student learning activeness using the Likert scale. If $p>0.05$, the distribution is declared normal, on the contrary, if $p<0.05$, the distribution is declared abnormal. The correlation results where $r x y=0.667$ with significant $p=0.000<0.050$. This means that the hypothesis proposed, the stronger the teacher's communication skills, the higher the student's learning activeness is accepted. The result of the determinant coefficient ( $r 2)$ of the relationship between the independent variable $X$ and the dependent variable $Y$ is $(r 2)=0.445$. This shows that the teacher's communication skills contribute to the active learning of students by $44.5 \%$. From these results it is known that there are still 55.5\% of the roles of various other factors that influence student learning activeness.
\end{abstract}

Keywords: Student Learning Activeness, Teacher Communication, Likert Scale

\begin{abstract}
ABSTRAK
Penelitian ini bertujuan untuk mengetahui Hubungan Antara Kemampuan Berkomunikasi Guru terhadap Keaktifan Belajar Siswa di Kecamatan Medan Polonia TA 2020/2021. Penelitian ini merupakan penelitian korelasi dengan menggunakan pendekatan deskriptif kuantitatif. Subjek dalam penelitian ini adalah 30 orang guru. Sebagai kriterianya untuk variabel kemampuan berkomunikasi guru dan keaktifan belajar siswa yang menggunakan skala likert. Apabila $\mathrm{p}>0,05$ sebarannya dinyatakan normal, sebaliknya dinyatakan apabila $\mathrm{p}<0,05$ sebarannya dinyatakan tidak normal. Hasil korelasi dimana $\mathbf{r}_{\mathrm{xy}}$ $=0.667$ dengan signifikan $\mathrm{p}=0.000<0,050$. Artinya hipotesis yang diajukan, semakin kuat kemampuan berkomunikasi guru maka semakin tinggi keaktifan belajar siswa dinyatakan diterima.Hasil Koefisien determinan $\left(\mathrm{r}^{2}\right)$ dari hubungan antara variabel bebas $\mathrm{X}$ dengan variabel terikat $\mathrm{Y}$ adalah sebesar $\left(\mathrm{r}^{2}\right)$ $=0.445$. Ini menunjukkan bahwa kemampuan berkomunikasi guru berkontribusi terhadap keaktifan belajar siswa sebesar $44.5 \%$. Dari hasil ini diketahui bahwa masih terdapat $55.5 \%$ peran dari berbagai macam faktor lain yang mempengaruhi keaktifan belajar siswa.
\end{abstract}

Kata Kunci : Keaktifan Belajar Siswa, Komunikasi Guru, Skala Likert

PENDAHULUAN

Belajar merupakan suatu kegiatan yang dilakukan oleh seseorang dengan sengaja atau disadari. Belajar adalah aktivitas yang menunjukkan $b$ ahwa seseorang aktif 
dalam melakukan aspek mental yang memungkinkan terjadinya perubahan pada diri seseorang. Dengan demikian, kegiatan belajar dapat dikatakan baik apabila intensitas keaktifan jasmani maupun mental seseorang semakin tinggi.

Mengajar dilakukan dengan tujuan untuk membantu siswa belajar, untuk itulah guru perlu untuk memperhatikan kualitas mengajar. Kualitas mengajar yang baik ada pada kualitas respons yang diberikan pengajar kepada siswa dalam proses belajar mengajar. Guru diharapkan mempunyai keterampilan untuk menciptakan iklim komunikatif dengan siswa. Dengan memiliki keterampilan dapat menciptakan iklim komunikatif maka siswa bisa berpartisipasi secara aktif untuk mengeluarkan pendapat, mengembangkan imajinasi dan daya kreativitas. Komunikasi guru dan siswa adalah kegiatan belajar mengajar dengan tatap muka baik secara verbal atau nonverbal, secara individual ataupun kelompok dan dibantu dengan media belajar.

Komunikasi merupakan alat untuk menjalin hubungan antar sesama sebagai makhluk sosial. Begitu pula dalam dunia pendidikan, komunikasi sangatlah penting untuk menyampaikan informasi pembelajar yang dilakukan antara guru (komunikator) dengan siswa (komunikan) pada saat proses belajar mengajar sedang berlangsung.

Sebagai seorang guru, guru dituntut agar memiliki kemampuan berkomunikasi yang baik, agar dapat menyampaikan informasi berupa materi pembelajaran dengan baik kepada siswanya. Proses belajar mengajar akan berlangsung dengan baik apabila siswa paham mengenai materi pembelajaran yang disampaikan oleh guru. Maka jika seorang guru tidak memiliki kemampuan berkomunikasi yang baik akan mengakibatkan siswa kurang aktif (pasif) dalam proses belajar mengajar atau pembelajaran.

Dalam proses pembelajaran guru merupakan tumpuan utama bagi seluruh siswanya, maka guru harus mampu merancang materi pembelajaran yang akan disampaikan dengan seksama agar dapat meningkatkan keaktifan belajar siswa. Sebab pembelajaran yang monoton dapat mengakibatkan kurang aktifnya siswa dalam proses pembelajaran didalam kelas sehingga akan berdampak rendahnya tingkat keaktifan siswa dan hasil belajar siswa. Jika keaktifan siswa dalam proses pembelajaran rendah maka akan mengakibatkan terjadinya proses pembelajaran yang monoton. Faktor penyebab kurang aktifnya siswa dalam pembelajaran yaitu guru kurang melibatkan siswa berperan aktif dalam kegitan pembelajaran, guru cendrung menggunakan metode ceramah, guru tidak variatif dalam menyesuaikan materi yang diajarkan pada saat kegiatan pembelajaran.

Pada saat sekarang ini masih banyak ditemukan guru yang masih menggunakan metode ceramah, guru tidak menggunakan media atau alat peraga pembantu dalam pelaksanaan proses pembelajaran. Sehingga berdampak kepada siswa, dimana 
siswa merasa bosan dan kurang tertarik pada saat guru menjelaskan materi pembelajaran di dalam kelas, sehingga tujuan pembelajaran yang ingin dicapai saat proses pembelajaran berlangsung tidak terlaksana. Hal ini berpengaruh terhadap keaktifan belajar siswa, sehingga siswa menjadi kurang aktif (pasif) dalam proses pembelajaran. Karena guru di dalam kelas hanya menggunakan metode ceramah sehingga siswa merasa bosan. Kurangnya guru dalam melibatkan siswa berperan aktif dalam kegitan pembelajaran mengakibatkan siswa menjadi kurang aktif (pasif) atau proses pembelajaran yang berlangsung menjadi kurang efektif.

Sebagai seorang guru, pendidik harus mampu mengatasi masalah dalam kemampuan berkomunikasi sehingga kegiatan belajar mengajar akan efektif, jika setiap peserta didik diberikan kesempatan untuk ikut serta dalam pembelajaran dengan kemampuannya masing-masing. Maka proses belajar mengajar yang berlangsung akan berjalan aktif, karena adanya timbal balik antara guru dengan siswa dalam proses pembelajaran yang sedang berlangsung.

Adapun fenomena kemampuan komunikasi guru yang terjadi di Kecamatan Medan Polonia TA 2020/2021 dari hasil wawancara yaitu masih kurangnya kemampuan berkomunikasi guru saat proses belajar mengajar berlangsung di dalam kelas. Cara mengajar yang dilakukan masih banyak menggunakan metode ceramah di depan kelas dan kurangnya guru melibatkan siswa berperan aktif dalam proses pembelajaran. Keaktifan belajar siswa tergantung cara mengajar yang di lakukan oleh guru, sehingga membuat siswa aktif pada saat proses belajar mengajar berlangsung.

Tidak semua siswa belajar dengan kecepatan yang sama. Ada yang terbilang cepat menguasai tapi ada juga yang sebaliknya. Bagi siswa yang tergolong lambat ajari secara pelan-pelan dan cek pemahaman mereka secara rutin agar tidak tertinggal dalam pelajaran, pastikan mereka tidak prustasi saat mempelajari konsep. Bagi para siswa yang memiliki kemampuan diatas rata-rata dan tergolong cepat memahami materi, berikan konsep tambahan sebagai ekstra, ini akan memberikan efek bagus bagi mereka dalam memperdalam materi.

Berdasarkan wawancara dilapangan dapat disimpulkan bahwa seorang guru harus lebih aktif dan lebih memperhatikan siswa untuk aktif dalam proses pembelajaran. Oleh karena itu para guru harus paham dengan materi yang diajarkannya. Semakin banyak ilmu yang dimiliki seorang guru, maka semakin besar pula kesempatan bagi siswa untuk mendapatkan ilmu yang lebih. Namun demikian, selain guru harus paham dan mengerti dengan materi yang diajarkannya, ia juga harus tahu metode-metdoe dalam kegiatan pembelajaran. Ilmu yang ditransfer dengan metode yang benar akan menghasilkan sesuatu yang positif, akan tetapi jika sang guru 
tidak mampu menerapkan metode dengan tepat maka ilmu yang dibagikannya tidak akan maksimal tersalurkan.

\section{METODE PENELITIAN}

Metode penelitian merupakan unsur penting dalam penelitian ilmiah, karena metode yang digunakan dalam penelitian dapat menentukan apakah penelitian tersebut dapat dipertanggungjawabkan hasilnya (sugiyono, 2016:116). Penelitian ini bersifat korelasional, yang bertujuan untuk melihat hubungan antara satu variable dengan variable lainnya. Pendekatan yang digunakan adalah deskriptif kuantitatif dimana pengumpulan data menggunakan instrument penelitian yaitu angket dan dokumentasi. Penelitian ini dilaksanakan pada bulan Juli sampai September 2020. Adapun tempat yang digunakan untuk penelitian ini adalah 5 Sekolah di Kecamatan Medan Polonia, yaitu: SD Angkasa 2 Lanud Soewondo, SD Al- Hidayah, SD Bundo Kandung, SD Islam Alief, SDN 060880. Variable adalah suatu sifat atau fenomena yang menunjukkan sesuatau yang dapat diminati dan nilainya berbeda-beda atau variable adalah gejala yang bervariasi menjadi obejek peneliti.

Populasi adalah seluruh individu yang mempunyai satu ciri atau sifat yang sama dengan subyek penelitian (Sugiyono, 2016:120).
Sedangkan subyek penelitian itu orang yang menjadi sumber data dan diambil dari populasi penelitian dan subyek penelitian merupakan sumber utama data penelitian, yaitu yang memiliki data mengenai variabel yang teliti. Pada dasarnya, subyek penelitian adalah yang akan dikenai kesimpulan hasil penelitian. Populasi dalam penelitian ini adalah seluruh SD di Kecamatan Medan Polonia yang berjumlah 17 Sekolah. Sampel merupakan perwakilan dari keseluruhan populasi sehingga harus memiliki karakteristik yang sama dengan populasi yang diwakili. Sampel harus menjadi refresentasi bagi populasi. Adapun metode pengambilan sampel yang dipakai dalam penelitian ini adalah menggunakan teknik Purposive Sampling.

Instrument penelitian ini berbentuk angket disusun dengan skala likert. Angket yang disusun dengan skala likert pada penelitian ini, subjek hanya diminta untuk memilih jawaban dengan memberikan tanda checklist $(\sqrt{ })$ pada kolom yang disediakan sesuai dengan keadaan yang sebenarnya. Dalam penelitian ini menggunakan skala likert dengan rentang 4. Skala ukur dalam penelitian ini antara lain: selalu, sering, kadang-kadang, dan tidak pernah. Pertanyaan diberikan skor sebagai: 
Tabel 1. Alternatif Jawaban dalam bentuk Skor

\begin{tabular}{l|c|l|c}
\hline \multicolumn{2}{c|}{ Item Positif } & \multicolumn{2}{c}{ Item Negatif } \\
\hline \multicolumn{1}{c}{ Jawaban } & Skor & \multicolumn{1}{c}{ Jawaban } & Skor \\
\hline Selalu & 4 & Selalu & 1 \\
\hline Sering & 3 & Sering & 2 \\
\hline Kadang - Kadang & 2 & Kadang - Kadang & 3 \\
\hline Tidak Pernah & 1 & Tidak Pernah & 4 \\
\hline
\end{tabular}

Tabel 2. Kisi-kisi Angket

\begin{tabular}{|c|c|c|c|c|c|}
\hline Variabel & \multirow[t]{2}{*}{ Indikator } & \multirow[t]{2}{*}{ Deskriptor } & \multicolumn{2}{|c|}{ Pernyataan } & \multirow[t]{2}{*}{ Jumlah } \\
\hline \multirow{8}{*}{$\begin{array}{l}\text { Keaktifan Belajar } \\
\text { Siswa }\end{array}$} & & & $(+)$ & $(-)$ & \\
\hline & \multirow[t]{3}{*}{$\begin{array}{l}\text { 1. Partisipasi } \\
\text { dalam kelas }\end{array}$} & $\begin{array}{l}\text { Mengemukakan } \\
\text { pendapat }\end{array}$ & 2,5 & 15 & 3 \\
\hline & & Bertanya & 4,9 & - & 2 \\
\hline & & $\begin{array}{l}\text { Menjawab } \\
\text { pertanyaan }\end{array}$ & 20 & - & 1 \\
\hline & \multirow{2}{*}{$\begin{array}{l}\text { 2.Kekompakan } \\
\text { kelas }\end{array}$} & Kerja kelompok & $1,6,12,13$ & 23 & 5 \\
\hline & & Kebebasan belajar & 16,25 & 3,24 & 4 \\
\hline & \multirow[t]{2}{*}{$\begin{array}{l}\text { 3. Kegiatan } \\
\text { emosional }\end{array}$} & Percaya diri & $\begin{array}{c}8,14,17 \\
19\end{array}$ & $\begin{array}{c}7,10,1 \\
8\end{array}$ & 7 \\
\hline & & $\begin{array}{l}\text { Memahami } \\
\text { pengetahuan }\end{array}$ & - & $\begin{array}{c}11,21 \\
22\end{array}$ & 3 \\
\hline \multicolumn{5}{|c|}{ Jumlah } & 25 \\
\hline Variabel & \multirow[t]{2}{*}{ Indikator } & \multirow[t]{2}{*}{ Deskriptor } & \multicolumn{2}{|c|}{ Pernyataan } & Jumlah \\
\hline \multirow{6}{*}{$\begin{array}{l}\text { Kemampuan } \\
\text { Berkomunikasi } \\
\text { Guru }\end{array}$} & & & $(+)$ & $(-)$ & \\
\hline & $\begin{array}{l}\text { 1.Kemampuan } \\
\text { Guru berbicara } \\
\text { Jelas }\end{array}$ & $\begin{array}{l}\text { Kemampuan guru dalam } \\
\text { menjelaskan pelajaran di } \\
\text { depan siswa }\end{array}$ & $1,4,8$ & 18 & 4 \\
\hline & \multirow[b]{2}{*}{$\begin{array}{l}\text { 2.Kemampuan } \\
\text { guru membuat } \\
\text { suasana kelas }\end{array}$} & $\begin{array}{l}\text { Memberikan pemahaman } \\
\text { yang jelas }\end{array}$ & 13,24 & $\begin{array}{l}11,15 \\
25\end{array}$ & 5 \\
\hline & & $\begin{array}{l}\text { Selalu membuat suasana } \\
\text { kelas menyenangkan }\end{array}$ & $\begin{array}{l}5,14 \\
16,20\end{array}$ & 3,7 & 6 \\
\hline & \multirow[b]{2}{*}{$\begin{array}{l}\text { 3.Kemampuan } \\
\text { memilih metode } \\
\text { belajar }\end{array}$} & Memotivasi siswa & $\begin{array}{c}2,6 \\
12,19\end{array}$ & 22 & 5 \\
\hline & & $\begin{array}{l}\text { Menanamkan nilai } \\
\text { positif }\end{array}$ & 9,17 & $\begin{array}{l}10,21 \\
23\end{array}$ & 5 \\
\hline \multicolumn{5}{|c|}{ Jumlah } & 25 \\
\hline
\end{tabular}

Uji Normalitas, yaitu untuk mengetahui apakah distribusi data penelitian masing-masing variabel telah menyebar secara normal.
Normalitas sebaran data merupakan syarat untuk menentukan jenis statistik yang digunakan dalam analisa selanjutnya. Jika data berdistribusi normal maka tidak 
normal maka uji statistik parametrik tidak dapat dilakukan, sehingga harus menggunakan statistik non parametrik (Sugiyono, 2010:75). Data berdistribusi normal apabila data tersebut membentuk kurva normal yaitu jika data di atas dan di bawah rata-rata adalah sama. Bentuk kurve adalah sistematis, sehingga luas ratarata ke kanan dan ke kiri masingmasing mendekati $50 \%$.

Menurut Sugiyono (2013:172) langkah-langkah dalam pengujian normalitas data menggunakan chi kuadrat adalah sebagai berikut:

- Merangkum seluruh variabel yang akan diuji normalitasnya

- Menentukan jumlah kelas interval 43

- Menentukan panjang kelas interval, yaitu (data terbesar-data terkecil) dibagi dengan jumlah kelas interval.

- Menyusun ke dalam tabel distribusi frekuensi, sekaligus merupakan tabel penolong untuk menghitung harga chi kuadrat.

- Menghitung frekuensi yang diharapkan (fh), dengan cara mengalikan presentase luas tiap bidang kurva normal dengan jumlah anggota sampel. 6) Memasukan harga-harga fh ke dalam tabel kolom fh, sekaligus menghitung harga (fh - fh) dan dan menjumlahkannya. Harga merupakan harga chi kuadrat hitung.
Uji Linearitas, yaitu untuk mengetahui apakah data dari variabel bebas memiliki hubungan yang linear dengan variabel terikat. Uji linieritas bertujuan untuk menguji apakah keterkaitan antara dua variabel yang bersifat linier. Perhitungan linieritas digunakan untuk mengetahui prediktor data peubah bebas berhubungan secara linier atau tidak dengan peubah terikat. Uji linieritas dilakukan dengan menggunakan analisis variansi terhadap garis regresi yang nantinya akan diperoleh harga $\mathrm{F}_{\text {Hitung. Harga }} \mathrm{F}$ yang diperoleh kemudian dikonsultasikan dengan harga $\mathrm{F}_{\text {Tabel }}$ pada taraf signifikan 5\%. Kriterianya apabila harga $\mathrm{F}_{\text {Hitung }}$ lebih kecil atau sama dengan $\mathrm{F}_{\text {Tabel }}$ pada taraf signifikan 5\% 44 maka hubungan antara variabel bebas dikatakan linier. Sebaliknya, apabila lebih besar dari pada, maka hubungan variabel bebas terhadap variabel terikat tidak linier (Burhan Nurgiyantoro, 2012:296). Semua data penelitian, mulai dari uji coba skala sampai kepada pengujian hipotesis, dianalisis dengan menggunakan komputer berprogram SPSS 21 (StatisticalPackage for the social Sciences) for windows.

\section{HASIL PENELITIAN DAN PEMBAHASAN}

Penelitian ini dilakukan di 5 SD di kecamatan medan polonia. Dengan jumlah guru sebanyak 30 orang. Pelaksanaan penelitian ini dilakukan pada bulan Agustus 2020. 
Tabel 3. Hasil Uji Validitas Angket Kemampuan Berkomunikasi Guru

\begin{tabular}{|c|c|c|c|}
\hline Sampel & r Hitung & r Tabel & Keterangan \\
\hline 1 & 0.565 & 0.316 & Valid \\
\hline 2 & 0.583 & 0.316 & Valid \\
\hline 3 & 0.528 & 0.316 & Valid \\
\hline 4 & 0.532 & 0.316 & Valid \\
\hline 5 & 0.457 & 0.316 & Valid \\
\hline 6 & 0.080 & 0.316 & Tidak Valid \\
\hline 7 & 0.435 & 0.316 & Valid \\
\hline 8 & 0.601 & 0.316 & Valid \\
\hline 9 & 0.535 & 0.316 & Valid \\
\hline 10 & 0.532 & 0.316 & Valid \\
\hline 11 & 0.528 & 0.316 & Valid \\
\hline 12 & 0.595 & 0.316 & Valid \\
\hline 13 & 0.648 & 0.316 & Valid \\
\hline 14 & 0.263 & 0.316 & Tidak Valid \\
\hline 15 & 0.596 & 0.316 & Valid \\
\hline 16 & 0.507 & 0.316 & Valid \\
\hline 17 & 0.574 & 0.316 & Valid \\
\hline 18 & 0.228 & 0.316 & Tidak Valid \\
\hline 19 & 0.596 & 0.316 & Valid \\
\hline 20 & 0.341 & 0.316 & Valid \\
\hline 21 & 0.532 & 0.316 & Valid \\
\hline 22 & 0.565 & 0.316 & Valid \\
\hline 23 & 0.532 & 0.316 & Valid \\
\hline 24 & 0.263 & 0.316 & Tidak Valid \\
\hline 25 & 0.252 & 0.316 & Tidak Valid \\
\hline
\end{tabular}

\section{Pembahasan}

Berdasarkan uji validitas dan uji reliabilitas alat ukur skala kemampuan berkomunikasi guru dari 25 aitem, terdapat 5 aitem yang gugur memiliki skor Corrected Item-Total Correlation (indeks daya beda rxy) < 0,3 ; yaitu aitem nomor $6,14,18,24$, 25. Dan 20 aitem lainnya valid memiliki skor Corrected Item-Total Correlation (indeks daya beda rxy) $\geq$ 0,3 ; dengan skor bergerak dari rbt $=$ 0.341 sampai $\mathrm{rbt}=0.648$, dengan skor reliabilitas (keandalan)
Cronbach Alpha 0.874, yang berarti skala kemampuan berkomunikasi guru tergolong reliable.

Analisis data yang digunakan dalam penelitian ini adalah teknik analisis korelasi product moment. Hal ini dilakukan dengan judul penelitian dan identifikasi variabelnya, dimana analisis korelasir Product Moment digunakan untuk menganalisis hubungan antara satu variabel bebas dan satu variabel terikat.

Sebelum data dianalisis dengan teknik analisis korelasi product 
moment, terlebih dahulu dilakukan teknik analisis data terhadap variabel yakni variabel kemampuan berkomunikasi guru dan variabel keaktifan belajar siswa yang meliputi uji normalitas, uji linearitas dan uji korelasi. Hasil uji normalitas sebaran dianalisis dengan menggunakan uji normalitas sebaran data penelitian menggunakan teknik KolmogorovSmirnov Goodness of Fit Test. Berdasarkan analisis tersebut, maka diketahui bahwa kemampuan berkomunikasi guru dan keaktifan belajar siswa mengikuti sebaran normal yang berdistribusi sesuai dengan prinsip kurva normal. Sebagai kriterianya untuk variabel kemampuan berkomunikasi guru dan keaktifan belajar siswa yang menggunakan skala likert, apabila $\mathrm{p}>$ 0,05 sebarannya dinyatakan normal.

Hasil uji linearitas dapat diketahui apakah variabel bebas dan variabel terikat dapat atau tidak dapat dianalisis secara korelasional. Hasil analisis menunjukkan bahwa variabel bebas (kemampuan berkomunikasi guru) mempunyai hubungan yang linear dengan variabel terikat (keaktifan belajar siswa) dengan kriteria $\mathrm{p}$ beda $<0.05$ maka dinyatakan mempunyai derajat hubungan yang linear.

Hasil analisis dengan metode analisis korelasi $r$ Product Moment, diketahui bahwa ada hubungan positif antara kemampuan berkomunikasi guru dengan keaktifan belajar siswa, dimana rxy $=0.667$ dengan signifikan $\mathrm{p}=0.000<0,050$. Artinya hipotesis yang diajukan, semakin kuat kemampuan berkomunikasi guru maka semakin tinggi keaktifan belajar siswa dinyatakan diterima.

Selain itu, Koefisien determinan (r2) dari hubungan antara variabel bebas $\mathrm{X}$ dengan variabel terikat $\mathrm{Y}$ adalah sebesar (r2) $=0.445$. Ini menunjukkan bahwa kemampuan berkomunikasi guru berkontribusi terhadap keaktifan belajar siswa sebesar 44.5\%. Dari hasil ini diketahui bahwa masih terdapat $55.5 \%$ peran dari berbagai macam faktor lain yang mempengaruhi keaktifan belajar siswa.

Hasil hipotetik untuk variabel kemampuan berkomunikasi guru, jumlah butir yang valid adalah sebanyak 20 butir yang diformat dengan skala likert dalam 4 pilihan jawaban, maka mean hipotetiknya adalah $\{(20 \times 1)+(20 \times 4)\}: 2=50$. Kemudian untuk variabel keaktifan belajar siswa jumlah butir yang valid adalah sebanyak 20 butir yang diformat dengan skala likert dalam 4 pilihan jawaban, maka mean hipotetiknya adalah $\{(20 \mathrm{X} 1)+(20 \mathrm{X}$ 4) $\}: 2=50$. Sedangkan mean empirik seperti yang terlihat dari deskriptif analisis diketahui bahwa mean empirik variabel kemampuan berkomunikasi guru adalah 74.23, sedangkan untuk variabel keaktifan belajar siswa, mean empiriknya adalah 66.63.

Dalam upaya mengetahui kondisi kemampuan berkomunikasi guru dan keaktifan belajar siswa, maka perlu dibandingkan antara mean/nilai rata-rata empirik dengan mean/nilai rata-rata hipotetik dengan 
memperhatikan besarnya bilangan SD dari masing-masing variabel. Untuk variabel kemampuan berkomunikasi guru bilangan SD nya adalah 5.770, sedangkan untuk variabel keaktifan belajar siswa bilangan SD adalah 6.563. Dalam penelitian ini, yakni diketahui kemampuan berkomunikasi guru dinyatakan baik. Hasil ini diketahui dengan melihat perbandingan nilai-nilai rata-rata empirik dengan nilai rata-rata hipotetik, dimana nilai rata-rata empirik lebih besar dari nilai rata-rata hipotetik dan selisih kedua nilai ratarata tersebut melebihi bilangan SD.

\section{SIMPULAN}

Berdasarkan hasil-hasil yang telah diperoleh dalam penelitian ini, maka dapat disimpulkan hal-hal sebagai berikut :

- Hasil analisis dengan metode analisis korelasi $r$ Product Moment, diketahui bahwa ada hubungan positif antara kemampuan berkomunikasi guru dengan keaktifan belajar siswa, dimana $r_{x y}=0.667$ dengan signifikan $\mathrm{p}=0.000<0,050$. Artinya hipotesis yang diajukan, semakin kuat kemampuan berkomunikasi guru maka semakin tinggi keaktifan belajar siswa dinyatakan diterima.

- Hasil upaya mengetahui kondisi kemampuan berkomunikasi guru dan keaktifan belajar siswa, maka perlu dibandingkan antara mean/nilai rata-rata empirik dengan mean/nilai rata-rata hipotetik dengan memperhatikan besarnya bilangan SD dari masing-masing variabel. Untuk variabel kemampuan berkomunikasi guru bilangan SD nya adalah 5.770, sedangkan untuk variabel keaktifan belajar siswa bilangan SD adalah 6.563. Dalam penelitian ini, yakni diketahui kemampuan berkomunikasi guru dinyatakan baik. Hasil ini diketahui dengan melihat perbandingan nilai-nilai rata-rata empirik dengan nilai rata-rata hipotetik, dimana nilai rata-rata empirik lebih besar dari nilai rata-rata hipotetik dan selisih kedua nilai rata-rata tersebut melebihi bilangan SD. Hasil Koefisien determinan $\left(r^{2}\right)$ dari hubungan antara variabel bebas $X$ dengan variabel terikat $\mathrm{Y}$ adalah sebesar $\left(r^{2}\right)=0.445$. Ini menunjukkan bahwa kemampuan berkomunikasi guru berkontribusi terhadap keaktifan belajar siswa sebesar 44.5\%. Dari hasil ini diketahui bahwa masih terdapat $55.5 \%$ peran dari berbagai macam faktor lain yang mempengaruhi keaktifan belajar siswa.

\section{DAFTAR RUJUKAN}

Ahmadi, Abu. 2012. Psikologi Belajar. Jakarta: Rineka Cipta.

Aunurrahman. 2012. Belajar dan Pembelajaran. Bandung: Alfabeta.

Brent, D. Ruben dan Lea P. Stewart. 2013. Komunikasi dan Perilaku Manusia. Jakarta: Raja Grafindo Persada. 
Effendy, Onong Uchjana. 2018. Ilmu,

Teori Dan Filsafat Komunikasi.

Bandung: Citra Adiya Bakti.

Halimatussakdiah \& Mahasiswa

Prodi PGSD C1 Reguler FIP

Unimed. 2017. Peningkatan

Keterampilan Berbahasa

Indonesia Pada Mahasiswa

PGSD. Medan: Unimed Press.

Majid, Abdul. 2014. Strategi

Pembelajaran. Bandung: Remaja

Rosdakarya.

Nofrion. 2018. Komunikasi

Pendidikan Penerapan Teori dan

Konsep Komunikasi Dalam

Pembelajaran. Jakarta: Prenada

Media Group.

Rusno. 2011. Faktor-Faktor Yang

Mempengaruhi Keaktifan

Mahasiswa Dalam Proses

Pembelajaran Mahasiswa

Program Studi Akutansi

Universitas Kanjuruhan Malang

Tahun 2011. Malang: Jurnal

Inspirasi Pendidikan Universitas

Kanjuruhan Malang.

Sanjaya, Wina. 2014. Media

Komunikasi Pembelajaran.

Jakarta: Kencana Prenada Media

Group.

Sardiman, A.M. 2011. Interaksi dan

Motivasi Belajar Mengajar.

Jakarta: Raja Grafindo Persada.

Sudjana, Nana. 2015. Dasar-Dasar

Proses Belajar Mengajar.

Bandung: Sinar Baru Algesindo.

Sugiyono. 2010. Metode Penelitian

Pendidikan. Bandung: Alfabeta

Indonesia.

Sugiyono. 2013. Metode Penelitian

Pendidikan. Bandung: Alfabeta

Indonesia.
Sugiyono. 2016. Metode Penelitian

Pendidikan:

Pendekatan

Kuantitatif. Kualitatif dan $R \& D$.

Bandung : Alfabeta

Sutikno, Sobry. 2013. Belajar Dan

Pembelajaran. Lombok:

Holistica. 